\title{
Intestinal parasitic infection effect on some blood components
}

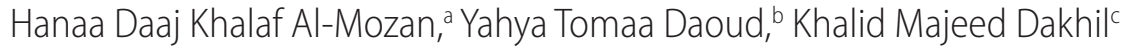

\author{
aBiology Department, Science College, Thi-Qar University, Iraq. \\ bBiology Department, Science for Women College, Baghdad University, Iraq. \\ Technical Institute in Nassiriyah, Iraq. \\ Correspondence to Hanaa Daaj Khalaf Al-Mozan (email: hanaa_daaj @yahoo.com). \\ (Submitted: 14 December 2016 - Revised version received: 27 December 2016 - Accepted: 10 January 2017 - Published online: 26 March 2017)
}

\begin{abstract}
Objectives To know the effect of intestinal parasitic infection on the differential count of white blood cells and sex factor effect on some blood criteria.

Methods The fecal samples were examined by direct and indirect methods. Blood samples were withdrawn for the testing of the differential count of white blood cells, Hb, PCV, T.WBC and numbers of eosinophils.

Results The results showed that AL-Jibaish General Hospital was the highest with parasitic infection (50.4\%) in comparison with other hospitals. A high percentage (30\%) of Entamoeba histolytica was formed. When compared with the percentage of each parasite under study between those hospitals, Entamoeba histolytica appeared with $12 \%$ in AL-Shatra and $46.6 \%$ in AL-Jibaish. There were significant differences between the parasite types in the percent of lymphocytes, neutrophils, monocytes and eosinophils. It ranged from increase and decrease according to parasite type. The significant difference appeared at the six-factor effect on the number of eosinophils was calculated by using the statistical analysis $\left(X^{2}\right)$ in level $P<0.05$.

Conclusion E. histolytica is the most common parasite. AL-Jibaish district suffers from a lack of services. There is no effect on the sex factor on blood criteria. Each one parasite has a different effect on blood components.

Keywords intestinal parasites, white blood cells, Entamoeba histolytica, haemoglobin
\end{abstract}

\section{Introduction}

Intestinal parasitic infection is a serious public health problem throughout the world particularly in developing countries. It is estimated that intestinal parasites infect more than three billion people worldwide. ${ }^{1,2}$ These parasites cause several symptoms, including: diarrhea, fever, vomiting, coughing, anorexia, gas or bloating and anemia. ${ }^{3}$ Anemia in children can be caused by iron deficiency and by health factors such as parasitic infection. ${ }^{4}$ Many studies have shown that hook worm causes chronic intestinal blood loss, ${ }^{5}$ blood loss can also occur by Trichuris infection. ${ }^{6}$

Hemoglobin is the red pigment in red cell. Its loss occurs in some pathological conditions including: parasitic infection, malnutrition, blood loss and chronic infection, ${ }^{7}$ which is expressed anemia. ${ }^{8}$ Packed cell volume has relation with anemia where the loss of packed cell volume occurs as a result of specific conditions such as anemia. ${ }^{9}$ White blood cells are considered as one of the basic components of blood and present in peripheral blood, ${ }^{10}$ to provide defense against germs, parasites and tumors as well as other diseases. ${ }^{11}$

There are five types of white blood cells vary in size, proportions and functions which are as follow: neutrophils, eosinophils, basophils, lymphocytes and monocytes. ${ }^{9}$

\section{Materials and Methods}

\section{Stool Samples}

Specimens were collected in clean containers to avoid contamination with urine, water or any other disinfectants. The stool samples were examined by the naked eye for color, odor, and the presence of blood or mucus. ${ }^{12,13}$ Finally, they were examined microscopically by the direct method using normal saline and Lugol's iodine, ${ }^{14,15}$ and indirect method by floatation with zinc sulfate. ${ }^{12,13}$

\section{Blood Samples}

Blood samples $(1 \mathrm{ml})$ were withdrawn by intravenous injection with sterile medical device and transferred to plastic tubes that contain the anticoagulant EDTA (ethylene diamine tetra acetic acid) and performed the following tests:

\section{Packed Red Blood Cell Volume}

Capillary tubes were filled with blood to three quarters. They were blocked at the end by artificial mud and wiped from outside. Then they were put in Microhematocrit rotor with speed $13000 \mathrm{r} / \mathrm{min}$ for $5 \mathrm{~min}$. Packed cell volume was read by using Microhematocrit reader. ${ }^{9,16}$

\section{Measurement of $\mathrm{Hb}$}

Hb was measured by a Reflotron plus, the product by a German company Roche established in accordance with the accompanying instructions of the company as follow:

A limited volume of blood was taken by micropipette that accompanying with apparatus. Blood was put on the exact location of the accompanying tape. There are some tapes were provided from company with apparatus, and there certain place (limited place) in the apparatus for the tape (to insert the tape) for it in the apparatus and was left for $3 \mathrm{~min}$ where the result appears on the screen of the apparatus and taking into account the zero of the apparatus before each using.

\section{Total Leukocytes Count}

Blood was put in tube contain EDTA. Blood was taken by specific pipette for white blood cells count to gradient 0.5 that is 
marked on the pipette tube (20 micrometers). Diluted liquid was withdrawn to the mark $11(0.4 \mathrm{ml})$ and was mixed by hand until became homogenous. The solution was put in neubaur chamber and a cover slip was put on it. The chamber was left for $2 \mathrm{~min}$ to settle the cells. Then, the cells were calculated under the microscope by the objective lens.

\section{Differential Count of White Blood Cells}

A drop of blood was put on a clean slide and was pulled by the edge of another slide taking into account the good distribution of the cells on smear. The slide was left to dry and was stained by Leishman stain and was left to dry with room temperature then 100 cells of white blood cells were calculated using oily lens. The absolute number of each type of white blood cells in millimeter per cubic was extracted from the total count of white blood cells and percent of each type of white blood cells. ${ }^{9,18,19}$

\section{The Statistical Analysis}

The statistical analysis was performed by using $t$-test and Chi-square test $\left(\chi^{2}\right)$ according to for 20 .

\section{Results}

Intestinal parasite infection was found in 333 from total 1001 fecal samples of children aged seven years and less than that age who visited different hospitals in Thi-Qar Province. Entamoeba histolytica appeared with percent 12\% in AL-Shatra and $46.6 \%$ in AL-Jibaish, as for the rest parasites $H$. nana, E. vermicularis, E. coli, T. homimis and $G$. lamblia, the statistical analysis $\left(\chi^{2}\right)$ in level $P<0.05$ not found significant differences between the hospitals forward those parasites (Table 1).

As for differential count of white blood cells, the results were changed either by excess from the normal criteria of blood or by decrease from the normal criteria of blood and in both cases the results were changed from the normal level. In other word there is effect of some parasites either by increase or by decrease according to type (species) of parasite while some types of parasites haven't effect where the percent of lymphocytes was $71 \%$ at infection with $G$. lamblia and 33\% with (E. histolytica + G. lamblia + T. hominis), neutrophils with $23.5 \%$ when infection by G. lamblia and $64 \%$ when infection by E. histolytica $+G$. lamblia $+T$. hominis. Monocytes appeared with $13 \%$ at G. lamblia $+H$. nana and $1 \%$ with infection by E. histolytica $+H$. nana, eosinophils with $6 \%$ at infection by (G. lamblia $+H$. nana), (E. histolytica $+H$. nana) and $0 \%$ when the infection of $E$. histolytica + G. lamblia + T. hominis, and the differences were significant. And 3\% represented the highest rate for basophils at infection with G. lamblia $+H$. nana. When statistical analysis compared between the percentages of white blood cells for the infected children with the percentages of white blood cells for non-infected children found some of them near and other far according to parasite type (Table 2).

As for the effect of sex, a number of eosinophils were 154.3 cells $/ \mathrm{mm}^{3}$ in an infected male and $218.0 \mathrm{cell} / \mathrm{mm}^{3}$ in an infected female. No significant differences for the effect sex on criteria $\mathrm{Hb}, \mathrm{PCV}$ and $\mathrm{WBC}$ in those infected children (Table 3).

\section{Discussion}

E. histolytica with $30 \%$ represented the most common intestinal parasite in this study, which is in agreement with previous studies. ${ }^{21,22}$ E. histolytica is the highest prevalence in the world specially in tropical and sub tropical countries, and Iraq is represented as one of them. ${ }^{23}$ The humid climate provides favourable environmental conditions for the maturity cyst of Entamoeba, ${ }^{24}$ and then transmit it to human $^{25}$ in addition to E. histolytica that can transmit directly (without need intermediate host). ${ }^{23}$

The presence high percentage of infection in AL-Jibaish may due to marginalization of the district from all services, such as healthy or environmentally, culturally and educationally also. Dryness marshes and assemblage brackish water and breeding

\begin{tabular}{|c|c|c|c|c|c|c|c|c|c|c|c|c|}
\hline \multirow[t]{2}{*}{ Type of parasite } & \multicolumn{2}{|c|}{$\begin{array}{c}\text { Nassiriyah } \\
\text { maternity and } \\
\text { children hospital }\end{array}$} & \multicolumn{2}{|c|}{$\begin{array}{l}\text { Suq-AL-Shuyukh } \\
\text { general hospital }\end{array}$} & \multicolumn{2}{|c|}{$\begin{array}{c}\text { AL-Shatra } \\
\text { general hospital }\end{array}$} & \multicolumn{2}{|c|}{$\begin{array}{l}\text { AL-Rifaai general } \\
\text { hospital }\end{array}$} & \multicolumn{2}{|c|}{$\begin{array}{c}\text { AL-Jibaish } \\
\text { general hospital }\end{array}$} & \multicolumn{2}{|c|}{ Total infection } \\
\hline & $\begin{array}{l}\text { No. of } \\
\text { infected }\end{array}$ & $\%$ & $\begin{array}{c}\text { No. of } \\
\text { infected }\end{array}$ & $\%$ & $\begin{array}{c}\text { No. of } \\
\text { infected }\end{array}$ & $\%$ & $\begin{array}{c}\text { No. of } \\
\text { infected }\end{array}$ & $\%$ & $\begin{array}{c}\text { No. of } \\
\text { infected }\end{array}$ & $\%$ & $\begin{array}{c}\text { No. of } \\
\text { infected }\end{array}$ & $\%$ \\
\hline E. histolytica & 93 & 40.1 & 50 & 30.1 & 31 & 12 & 65 & 30.5 & 61 & 46.6 & 300 & 30.0 \\
\hline G.lamblia & 11 & 4.8 & 12 & 7.2 & 5 & 2 & 5 & 2.3 & 3 & 2.3 & 36 & 3.6 \\
\hline T. hominis & 0 & 0.0 & 2 & 1.2 & 0 & 0.0 & 0 & 0.0 & 0 & 0.0 & 2 & 0.2 \\
\hline E. coli & 0 & 0.0 & 0 & 0.0 & 0 & 0.0 & 0 & 0.0 & 1 & 0.8 & 1 & 0.1 \\
\hline E. vermicularis & 3 & 1.3 & 0 & 0.0 & 2 & 0.8 & 0 & 0.0 & 0 & 0.0 & 5 & 0.5 \\
\hline H. nana & 0 & 0.0 & 1 & 0.6 & 1 & 0.4 & 0 & 0.0 & 1 & 0.8 & 3 & 0.3 \\
\hline Total & 107 & 46.1 & 65 & 39.1 & 39 & 15.1 & 70 & 32.9 & 66 & 50.4 & 347 & 34.7 \\
\hline \multirow[t]{2}{*}{$X^{2}$ Calculated } & \multicolumn{2}{|c|}{ E. histolytica } & \multicolumn{2}{|c|}{ G. lamblia } & \multicolumn{2}{|c|}{ T. hominis } & \multicolumn{2}{|c|}{ E. coli } & \multicolumn{2}{|c|}{ E. vermicularis } & \multicolumn{2}{|c|}{ H. nana } \\
\hline & \multicolumn{2}{|c|}{21.68} & \multicolumn{2}{|c|}{5.88} & \multicolumn{2}{|c|}{0.00} & \multicolumn{2}{|c|}{0.00} & \multicolumn{2}{|c|}{0.00} & \multicolumn{2}{|c|}{0.00} \\
\hline Sig. & \multicolumn{2}{|c|}{$0.001^{*}$} & \multicolumn{2}{|c|}{0.20} & \multicolumn{2}{|c|}{$\underline{-}$} & 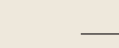 & & \multicolumn{2}{|c|}{1.00} & \multicolumn{2}{|c|}{1.00} \\
\hline
\end{tabular}




\begin{tabular}{|c|c|c|c|c|c|}
\hline Type of parasite & $\begin{array}{c}\text { Lymph \% } \\
\text { Mean } \pm \text { SD }\end{array}$ & $\begin{array}{c}\text { Neutro.\% } \\
\text { Mean } \pm \text { SD }\end{array}$ & $\begin{array}{c}\text { Mono. \% } \\
\text { Mean } \pm \text { SD }\end{array}$ & $\begin{array}{c}\text { Eosino.\% } \\
\text { Mean } \pm \text { SD }\end{array}$ & $\begin{array}{c}\text { Baso. \% } \\
\text { Mean } \pm \text { SD }\end{array}$ \\
\hline $\begin{array}{l}\text { E. histolytica } \\
N=288\end{array}$ & $40.8 \pm 16.49$ & $53.3 \pm 18.81$ & $4.4 \pm 2$ & $1.3 \pm 0.6$ & $0.2 \pm 0.15$ \\
\hline $\begin{array}{l}\text { G.lamblia } \\
N=24\end{array}$ & $71 \pm 26.87$ & $23.5 \pm 2.12$ & $2.5 \pm 0.7$ & $3 \pm 2.4$ & $0 \pm 0.00$ \\
\hline $\begin{array}{l}\text { E. vermicularis } \\
N=5\end{array}$ & $44.5 \pm 2.82$ & $49.5 \pm 7.77$ & $4 \pm 1.5$ & $2 \pm 1.7$ & $0 \pm 0.00$ \\
\hline $\begin{array}{l}\text { H. nana } \\
N=1\end{array}$ & $47 \pm 0.00$ & $42 \pm 0.00$ & $4 \pm 0.00$ & $5 \pm 0.00$ & $2 \pm 0.00$ \\
\hline $\begin{array}{l}T \text {. hominis } \\
N=1\end{array}$ & $35 \pm 0.00$ & $56 \pm 0.00$ & $5 \pm 0.00$ & $3 \pm 0.00$ & $1 \pm 0.00$ \\
\hline $\begin{array}{l}\text { E. coli } \\
N=1\end{array}$ & $42 \pm 0.00$ & $47 \pm 0.00$ & $5 \pm 0.00$ & $4 \pm 0.00$ & $2 \pm 0.00$ \\
\hline $\begin{array}{l}\text { E. histolytica + G. lamblia } \\
N=10\end{array}$ & $49 \pm 9.1$ & $46 \pm 8.62$ & $3 \pm 1.15$ & $1 \pm 0.7$ & $1 \pm 0.4$ \\
\hline $\begin{array}{l}\text { E.histolytica + H. nana } \\
N=1\end{array}$ & $51 \pm 0.00$ & $42 \pm 0.00$ & $1 \pm 0.00$ & $6 \pm 0.00$ & $0 \pm 0.00$ \\
\hline $\begin{array}{l}\text { G.lamblia + H. nana } \\
N=1\end{array}$ & $45 \pm 0.00$ & $33 \pm 0.00$ & $13 \pm 0.00$ & $6 \pm 0.00$ & $3 \pm 0.00$ \\
\hline $\begin{array}{l}\text { E. histolytica }+ \text { G. lamblia }+ \text { T. hominis } \\
N=1\end{array}$ & $33 \pm 0.00$ & $64 \pm 0.00$ & $3 \pm 0.00$ & $0 \pm 0.00$ & $0 \pm 0.00$ \\
\hline $\mathrm{T}_{\text {Calculated }}$ & 13.77 & 12.51 & 4.39 & 4.71 & 2.68 \\
\hline $\begin{array}{l}\text { Non infected } \\
N=100\end{array}$ & $37.5 \pm 12.64$ & $54 \pm 15.43$ & $6 \pm 2.19$ & $2.3 \pm 0.92$ & $0.2 \pm 0.26$ \\
\hline
\end{tabular}

\begin{tabular}{|c|c|c|c|c|}
\hline \multirow[t]{2}{*}{ Tests } & \multicolumn{2}{|c|}{ No. of infected } & \multirow[t]{2}{*}{ Calculated $X^{2}$} & \multirow[t]{2}{*}{ Sig. } \\
\hline & $\begin{array}{c}\text { Male } N=175 \\
\text { Mean } \pm \text { SE }\end{array}$ & $\begin{array}{c}\text { Female } N=158 \\
\text { Mean } \pm \text { SE }\end{array}$ & & \\
\hline $\mathrm{Hb} \mathrm{g} / 100 \mathrm{ml}$ & $11.1 \pm 0.32$ & $11.8 \pm 0.44$ & 0.04 & 0.83 \\
\hline $\begin{array}{l}\text { PCV } \\
\text { cell/ } / \mathrm{mm}^{3}\end{array}$ & $33 \pm 0.85$ & $34.1 \pm 0.88$ & 0.95 & 0.90 \\
\hline $\begin{array}{l}\text { WBC } \\
\text { cell/mm }\end{array}$ & $8573.5 \pm 908.74$ & $8385.7 \pm 998.81$ & 2.08 & 0.14 \\
\hline $\begin{array}{l}\text { Number of } \\
\text { eosinophile } \\
\text { cell } / \mathrm{mm}^{3}\end{array}$ & $154.3 \pm 33.92$ & $218.0 \pm 37.57$ & 11.01 & $0.001^{*}$ \\
\hline
\end{tabular}

N, Number; $X_{\text {Tabulated }}^{2} 3.84 ; P<0.05$.

animals in the houses led to attract huge number of insects that transfer diseases as well as vegetable cultivation by the population of that region and frequent eating it certainly does not help them to avoid the danger of its contamination, moreover drinking water of rivers and ponds without hesitation.

As for differential count of white blood cells, the reason of presence significant differences between parasites, $S$ types in percent of lymphocytes, neutrophils, monocytes eosinophils except basophils may be due to variation of damage nature that caused by each type of parasites (where worms usually more effect than protozoa on blood criteria) and variation of importance and work each cell of white bloods cells and immunity of patient.

There is no significant difference for sex effect on $\mathrm{Hb}$ and PCV which is in agreement with the past research ${ }^{26}$ and disagreement with other research. ${ }^{27}$ There were no significant differences on the total count of white blood cells between males and females which is in agreement with the already published research. ${ }^{26,27}$ It was found that sex factor effect on the number of eosinophils which is disagreement with Refs. 26 and 27. The reason may belong to that both double infections with (E. histol$y$ tica $+H$. nana $)$ and $(H$. nana + G. lamblia $)$ in which the number of eosinophils increased with them. They have occurred in females excluding males.

\section{Conclusion}

E. histolytica is the most common parasite in Thi-Qar province. AL-Jibaish district was the highest with intestinal parasitic infection as a result of lack of services. There is no effect for sex factor on blood criteria of infected children with intestinal parasitic where variations that occurred on blood criteria depend on parasite, $S$ type.

\section{Recommendations}

The study must be performed on parasites that resides in the blood. Pay attention with hygiene and aren't eaten fruits and vegetables unless after being washed. Increased of attention with elimination of the vectors such as insects. Increased of attention with AL-Jibaish district from all aspects and progress in it to the level that deserve it for being represent rural identity of Iraq.

\section{Conflict of Interest}

None. 


\section{References}

1. Markell EK, John DT, Krotoski WA. Markell and Voge's Medical Parasitology. $8^{\text {th }}$ ed. Philadelphia: W.B. Saunders 1999.

2. WHO Intestinal parasites. Available at: http://Apps.Who.Int/ctd/intpara/ burdens.htm 2010

3. Dariel J. Cleanse and purify thyself book one. Medford, Oregon. Christobe Publishing, U.S.A 2007.

4. I.N.A.C.G. Guidelines for eradication of iron deficiency anemia. A report of the international nutritional anemia consultative group (INACG). New York, Washington, Nutrion foundation 1997.

5. Crompton D. The Public health importance of hook worm disease. Parasitology. 2000;121:39-50.

6. Stephenon LS, Holland CD, Cooper ES. The public health significance of Trichuris trichiura. Parasitology. 2000;121:73-95.

7. AL-Asady HAR. Epidemiological study for some pathogenic intestinal parasites with focus on viability of Entamoeba histolytica in Basrah city. PhD thesis, College of sciences, AL-Basrah university 2007.

8. AL-Quraishy AAS. Study on anemia realty in AL-Qadisiya province during economic resource period. PhD thesis, College of education, AL-Qadisiya university 2002.

9. Harmening DM. Clinical Hematology and Fundamentals of Hemostasis. Fifth edition. United States of America F.A. Davis Company. Philadel phia 2009.

10. Goldsby T, Thomas J, Osborne BA. Immunology $4^{\text {th }}$ ed. W.H. Freeman Comp., New York, 2000;25.

11. Junqueira LC, Carneiro J. Basic Histology. $10^{\text {th }}$ ed., Prentice - Hall International Inc. U.S.A 2003.

12. Ichhpujani RL, Bhatia R. Medical Parasitology, $1^{\text {st }}$ ed. Jaypee Bros. Med. Publ., New Delhi 1994

13. Paniker CJ. Textbook of Medical Parasitology. $6^{\text {th }}$ ed. New Delhi. Jaypee Brothers Medical Publishers 2007.

14. Lumsden WH, Burns S, McMillan A. Protozoa in practical medical microbiology. By Collee JG, Marmion BP, Fraser AG and Simmons A. Churchill Livingstone, Tokyo 1996.

15. Zeibig EA. Clinical Parasitology: A practical approach. W.B. Saunders Company, Philadelphia 1997.
16. Jubouri, Talal Hamad; Ali Musa. Epidemiological study of patients with clinical and Giardia Giardiasis in children Shirqat city 2008.

17. Ahamid AS, Salhi EM. Practical physiology for community Health departments. Ministry of Higher Educ. \& Scientific Research, foundation of Technical institutes. AL-Mosul Univ. Press 1994.

18. Talib VH, Khurana SR. A Handbook Of Medical Laboratory Technology . $5^{\text {th }}$ ed., C.B.S. Publ., New Delhi. Philadelphia 1996.

19. Lewis SM, Bain BJ, Bates I. Dacie and Lewis Practical Hematology. $9^{\text {th }}$ ed. Churchill Livingstone 2001.

20. AL- beldawi AA. Manners of Statistics. First edition. Jordan, D. W. for Publishing and Distribution 2009.

21. AL-Rekabi, Nuha Jabbar. A study of some intestinal parasites that cause diarrhea in children in the city of Nasiriyah. Master Thesis. Faculty of Education - University of Thi-Qar. 2006;92.

22. Wadood UA, Bari A, Rhman AU, Qasim KF. Frequency of Intestinal Parasite Infestation in Children Hospital Quetta. Pakistan J Med Res. 2005;44.

23. Razmjou E, Rezaian M, Haghighi A, Kazemi B, Farzami B, Kobayashi S, et al. Comparison of the recombinant glucose phosphate isomerase from different zymodems of Entamoeba histolytica with their natural counterparts by isoenzyme electrophoresis. Iranian J Publ health. 2005;34:35-40.

24. Egwunyenga A, Ataikiru DP. Soil - transmitted helminthiasis among school age children in Ethiope East Local Government Area of Delta State, Nigeria. Afri J Biotech. 2005:4:938-941.

25. Garba CMG, Mbofung CMF. Relationship between malnutrition and parasitic infection among school children in the Adamawa Region of Cameroon. Pakistan J Nutr. 2010;9:1094-1099.

26. Al-Zubaidi, Zainab Hadi. Worm hookworm Ancylostoma duodenale and its impact on the image Mhimh blood in the village in the province of Babylon. Master Thesis. Faculty of Science - University of Babylon. 2002.

27. AL-khalifawi, Mohammad Jubair. Study of the parasites of the gastrointestinal tract in children under five and their impact on some of the blood levels: Master - Faculty of Science - University of Mustansiriya: 2006;92.

This work is licensed under a Creative Commons Attribution-NonCommercial 3.0 Unported License which allows users to read, copy, distribute and make derivative works for non-commercial purposes from the material, as long as the author of the original work is cited properly. 